\title{
濃尾平野の長・短周期微動特性 (4)
}

\author{
一一たい積深さの異なる三サイトでの一週閒観測—
}

$\begin{array}{lllll}\text { 正会員 } & \text { 多 } & \text { 賀 } & \text { 直 } & \text { 恒* } \\ \text { 正会員 } & \text { 宮 } & \text { 崎 } & & \text { 正** }\end{array}$

\section{1. 序論}

筆者らは濃尾平野を対象とした地盤振動特性の検討と 耐震工学への利用を目的として, 地震動観測に比べて簡 便である微動観測を実施してきた。それらの結果につい ては既報1，22,3)で明らかにしてきた。

長周期微動特性に関する議論の一つとして，観測結果 の卓越周期が地盤固有の振動特性を反映しているのか, 振動源と称せられる波浪の周期特性 (ロンゲットーヒギ ンスの定常波説）に依存しているのかとの不明確さがあ る。この点を明らかにする事は, 長周期微動の観測結果 を工学的に利用するといら観点から極めて大切な事と言 える。関連して, 長周期微動の本性の解明に当って検討 する必要がある項目として，次の諸点が挙げられる。

I）地下構造と周期特性との対応性

III) 気象条件と微動特性との相関性

III）台風通過が微動特性に及ぼす影響

IV) 波浪と微動特性との因果関係

V) 微動特性の定常性

VI） 伝播性の有無と波動種別の判定

VII） 地震時の振動特性との相関性

筆者らは, 項目のVI) に関しては検討の緒についたば かりで, 今後の本格的な複数サイトでのトリパータイト 観測に待ちたい。VII）については，鏡味ほかによる青 森, 宮古, 八戸での報告 ${ }^{4}$ が見られ，筆者らも濃尾平野 内で若干の検討を試みた ${ }^{5)}$ 。文献 1)，2）で主として地下 構造と周期特性との対态関係について, 文献 3) は周 期・フーリエ振幅の季節的変化の様相の把握について, 文献 6) では長周期域の微動を対象とした伝播性に関す る予備的検討という手順で, 段階的な観測と解析を試み てきた。

既往の研究には，異常気象条件下で地艋状態が異なる 複数サイトにおいて，同時に長周期微動を観測した例は 見受けられない。本報は先に述べた項目の I ) V V を 検討する観点から, 固有周期 10 秒の地震計により一週

* 名古屋大学 助教授 $\cdot$ 工博

** 愛知県立任織工業高校 教諭・工修

（昭和 56 年 8 月 31 日原稿受理日，討論期限昭和 57 年 11 月末日）
間にわたって，三サイトで同時に，三成分観測を実施し た結果である。

本報での主眼は次のとおりである。

1）濃尾平野内の岩盤に至る堆積深さが $1000 \mathrm{~m}$ をは

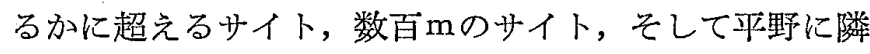
接し岩盤露頭に等しいサイトの合計三個所の地下構造状 態が䫓著に異なる場所を選択し，同一気象条件下で同時 観測をし，微動特性の相対的な比較をする。

2）台風の接近・通過化併い，スペクトル形状がいか に変化するか。そして, 風速・気圧の急変に伴い卓越振 動数・フーリエ振幅がどら変化するか。

3）台風下での波浪と微動特性に出現するその影響は どのようなもので, 相関関係はどうか。

4）以上の検討から, 地盤の固有振動特性の把握を明 確にする事に上り，長周期微動の工学的利用の有用性を 示す資料とする。

2. 気象変化・波浪と長周期微動に関する既往の研究 1903 年にヴィーヘルトによって脈動 (長周期微動) の 発生についての仮説が発表されて以来，脈動と波浪に関 する多くの研究がなされてきた。近年では，ロンゲッ ト一七ギンスによる定常波説 ${ }^{7}$ により，脈動の周期は波 浪のそれの $1 / 2$ であるとの観点からの検討がみられる。

本報での検討事項とも関わってくるので, 台風・サイ クロンの通過や波浪と長周期微動に関する既往の研究に ついて以下に整理する。

岸上による東京での土地の脈動と波浪の関係について の報告 ${ }^{8)}$ では，脈動と 波浪の周期の関係は明確ではない が各々の周期頻度分布の様相は似ているとし，岸上・小 高による台風の通過と日本列島の数個所での脈動の関倸 の報告 ${ }^{9}$ では，台風の中心気圧・進行速度・風速と脈動 の变位振幅の間には顕著な関係は無く, また台風の中心 までの距離と脈動の振幅の減衰性の関係から波動種別の 判定を試みたが，台風の状態によって恋動するとある。

三東 ${ }^{10)}$ にれば，国際地球観測年 (IGY) の期閒中の 日本各地で観測された脈動の資料から，脈動の発生源は 海岸線のどこかで波浪の定常波が生じ，そこから発生す るとしている。また，三東 ${ }^{11}$ は，スカンディナビアの観 
測と日本での場合を比較している。

池上・岸上による東京における脈動の伝播性に関する 一連の研究 ${ }^{12}$ に掠いて, 台風によって周期は, 約 3 秒加 ら 7 秒に変化した事を明らかにしている。

さらに，飯田・太田による名古屋における1サイトで の脈動と台風 (4ケース) の関係についての報告13)で は, 台風の中心までの距離が $1600 \mathrm{~km}$ 以上の時は, 脈 動の振幅・周期の頻度分布は平常通り，900 km では振 幅が大, $400 \mathrm{~km}$ で振幅が著しく大となる事，脈動嵐の 発生により卓越周期の約 3 秒に加うるに，第 2 ピークと して 5〜7 秒が出現し，また，台風のスケールが大き く, 办つ観測点の近くにある時は他の卓越周期 ( 5 秒) が見られるとの事である。

長周期微動を工学的に利用するといら立場加らすれ ば，以上の諸研究を踏まえて，波浪・気象因子を，長周 期微動の大力源，あるいは影響を与える要素と考えた 時, 地盤という媒体を経た後の出力結果である長周期微 動が，地盤の固有振動特性を示しているか否か，また， それがどのように変化するのかが関心あるテーマと言え よう。

\section{3. 観測概要・地下構造亡天気図・波浪}

図一1に示すごとく, 濃尾平野内に位置する $\mathrm{A}, \mathrm{B}$ の二 サイト，平野に隣接するCサイトの合せて三サイトにお いて長周期微動観測を実施した。使用機器は, 表一1に 示すと扔りで,基盤に至るたい積深さに対応させて $\mathrm{A}, \mathrm{B}$ サイトが 10 秒計，C サイトが 5 秒の地震計を使用した。

観測は，1979年10月13日18時から 10 月 20 日 16 時 までの一週開にわたり，2 時間ごとに三サイトで同じ時 間带に, 速度の水平動 (NS, EW), 上下動 (UD) 成分

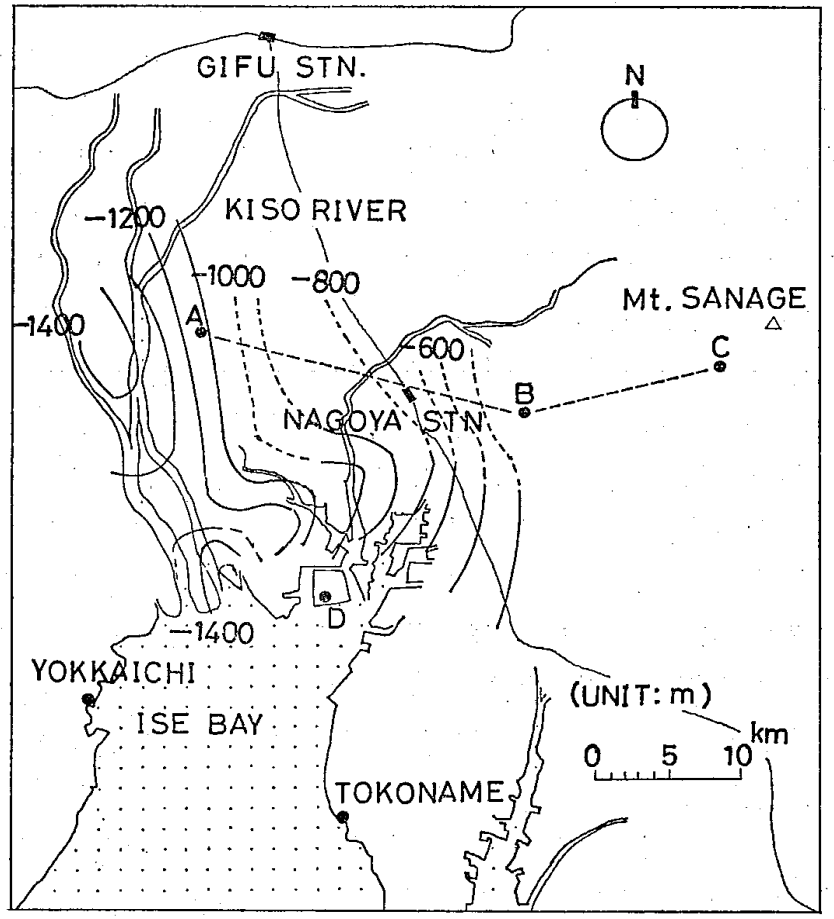

图一1 観測点分布と奄基濖群基底面等深線 ${ }^{14)}$
表一1 観測に使用した機器一覧

\begin{tabular}{|c|c|c|c|c|c|}
\hline & 地 震 計 & 增幅器 & フィル8ー & オッショススコープ & データーレコーダー \\
\hline $\begin{array}{l}A \\
+ \\
1 \\
1\end{array}$ & $\begin{array}{l}\text { 国有周期 } 10 \text { 秒 } \\
\text { NS感度 } 2.10 \mathrm{v} / \text { /kine } \\
\text { EW" } 2.10 \% \\
\text { UD } " 2.10 \%\end{array}$ & $\begin{array}{l}\text { 周波数特性 } \\
\mathrm{DC}-20 \mathrm{~Hz} \\
\lambda 力 \text { イイピ-ダスス } \\
1 \mathrm{MHz}\end{array}$ & 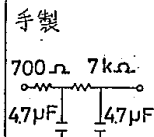 & $\begin{array}{l}\text { 周波数特性 } \\
\mathrm{DC}-\mathrm{TOMHz}\end{array}$ & \begin{tabular}{|l} 
周波数特性 \\
DC- $625 \mathrm{~Hz}$ \\
SN比 $44 \mathrm{~dB}$
\end{tabular} \\
\hline $\begin{array}{l}B \\
+ \\
1 \\
5\end{array}$ & $\begin{array}{l}\text { 固有周期 } 10 \text { 秒 } \\
\text { NS感度 } 2.26 \text { V/kine } \\
\text { EW" } 2.20 " \\
\text { UD" } 1.97 "\end{array}$ & 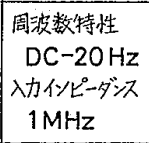 & 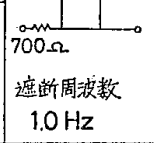 & $\begin{array}{l}\text { 周波数特性 } \\
\text { DC- } 1 \mathrm{MHz}\end{array}$ & $\begin{array}{l}\text { 周波数特性 } \\
\text { DC-625H } \mathrm{Hz} \\
\text { SN比 } 44 \mathrm{~dB}\end{array}$ \\
\hline $\begin{array}{l}c \\
+4 \\
1 \\
-\end{array}$ & $\begin{array}{l}\text { 固有周期 } 5 \text { 秒 } \\
\text { NS 感度 } 0.66 \text { v/kine } \\
\text { EW" } 0.66 \% \\
\text { UD" } 0.40 \%\end{array}$ & 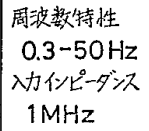 & $\begin{array}{l}\text { LPF確度 } \$ 3 \% \\
\text { 遮断特性 } \\
18,30,42 \% \mathrm{ct}\end{array}$ & $\begin{array}{l}\text { 周波数特性 } \\
\text { DC-100kHz }\end{array}$ & \begin{tabular}{|l} 
周波数特姓 \\
DC-1.25kHz \\
SN比 $41 \mathrm{~dB}$
\end{tabular} \\
\hline
\end{tabular}

の同時三成分を収録した。地震計の設置個所は，Aサイ 卜は屋外，B・C サイトは建築物内で㐫った。観測途中 で台風 20 号 (T 7920 号) が濃尾平野を通過した事によ り，Aサイトで観測不可能に陥ったし，Bサイトでは停 電により同様の事態となった時間帯がある。

次に，三個所の観測点の地下構造がいかなる特微を有 している汃説明する。図一1の中に示した等深線は既 報2に扔いて触れたが，新第三紀のほぼ下底に位置して いる奄芸層群の美麗層の下限を意味する ${ }^{14)}$ 。濃尾平野の 地下構造は，基盤が東から西へ緩く傾斜しその上に各地 層がたい積したとされており，図一1 から基盤に至る堆 積深さは，A サイトでは $1000 \mathrm{~m}$ をはるが越え，Bサ イトでは数百 $\mathrm{m}$ 程度と推測される。な社文献 15) によ れば， 1980 年 3 月 23 日に，図一1 のDサイトにおいて 実施した名古屋地方深部構造探查のための人工爆破実験 から，基盤深さは約 $2 \mathrm{~km}$ 程度と推定している。

襄尾平野東部では洪積層が露頭しているが，観測点の 地層状態を知るため, 断面模式図を図一 2 に示寸。同図 から，猿投山の西方へ約 $5 \mathrm{~km}$ の以置にあるCサイトで は，平野酉部の羡老断層位置での深い基盤注東人浅くな り猿投山の位置で露頭しているとの報告 ${ }^{143}$ 加らも，ほぼ 基盤露頭の状態に等しいと考学られる。

一方, 観測期間中の午後 6 時の名古屋地方気象台発表 による天気図を図一にに示す。同図から濃尾地方では， 10月 19 日の午前中から台風の強い影響下にあったが， 波浪のらねりの影響は観測当初から現わ叔ていたを推測

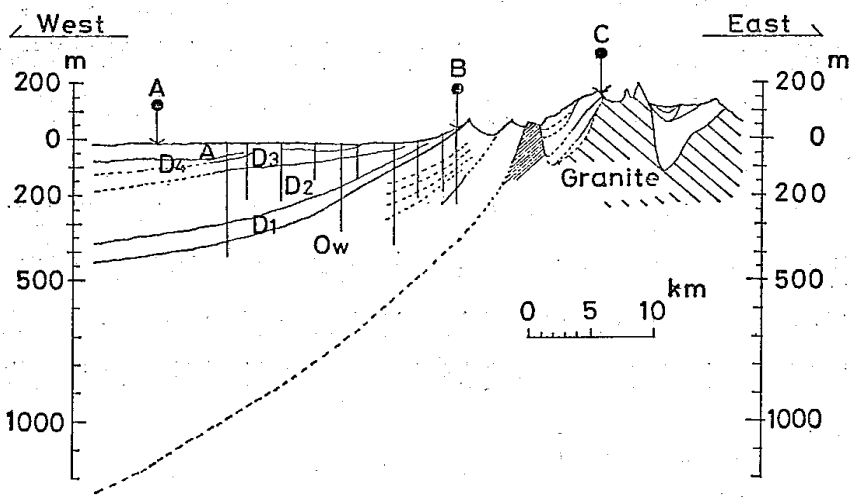

圆一2 断面模式図 ${ }^{14)}$ 


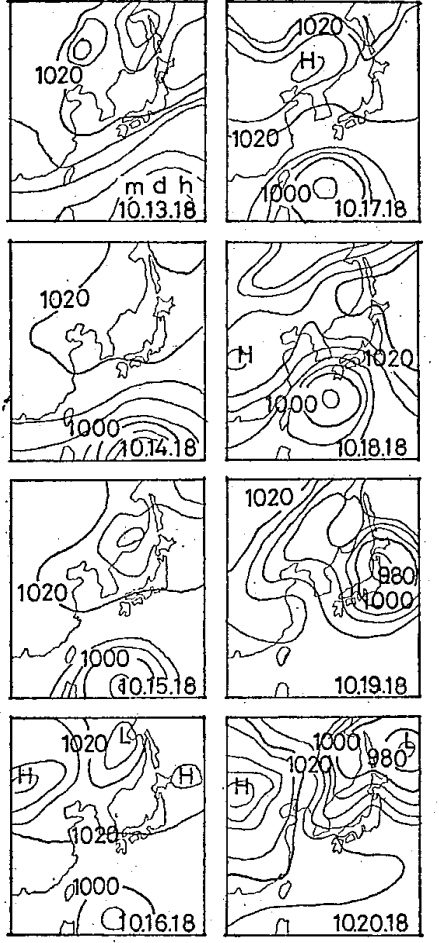

図一3＼cjkstart観測期閒中の天気㘠

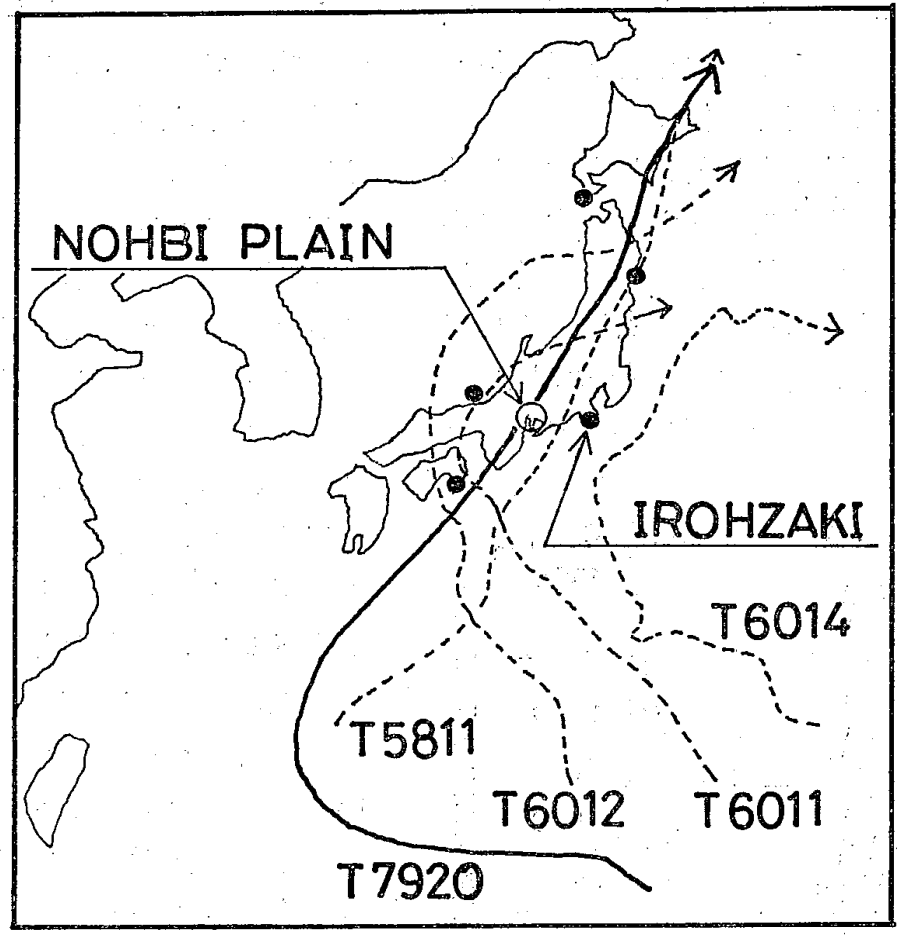

図-4 気象庁波浪観測点 ${ }^{16)}$ と台栭経路 ${ }^{13)}$
前報までは ${ }^{1), 2), 3) ， ~}$ 長周期域にウェイトを 置きながらも短周期域 に関しても検討を加え てきた。本報では，基 盤に至る媣いたい積層 厚, 或は台風との関連 で検討を実施する観点 から，長周期域安対象 に諭ずる事にする。

各サイトの 2 時間ご との合計 84 回分のス ペクトルは，波形同様 に図形出力により求め た。図一3 に示した天 気图で明らかなごと く，観測開始日に，台 風 ( T 7920 号) は濃尾 平野からはるか 2000 $\mathrm{km}$ の海洋上に位置し
される。そこで次に観測期間中の波浪がいかなる状態で むったのかについて触れる。気象庁では, 現在図一4に 示すごとく全国で五個所（黒好印）に水中発射型超音波 波浪計を沖合 $1 \sim 2 \mathrm{~km}$ の水深 $50 \mathrm{~m}$ 付近に設置し ${ }^{16)}, 3$ 時間ごとの観測と解析処理を実施しており，本報では波 浪観測点と漂尾平野の位置を考慮して, 石廊崎沖での記 録 ${ }^{16)}$ 索参考にする（図一4 に示した台風経路は，4-3 節 で触れるが，実線が本研究時，破線注飯田・太田 ${ }^{13)}$ によ る報告に打けるものである)。

図一5 亿文献 16) 加ら， 1979 年の石廊崎沖での $1 / 3$ 有義波（波高の大きい方か ら 1/3 以内に分布している 波)の周期の出現頻度分布 を示す。秋季 $(9 \sim 11$ 月)に おける周期頻度の最高頻度 は, 6.0〜7.9 秒に出現し， 冬・春・夏季の分布は, 6.0 〜6.9 秒に最高頻度が見ら れる。

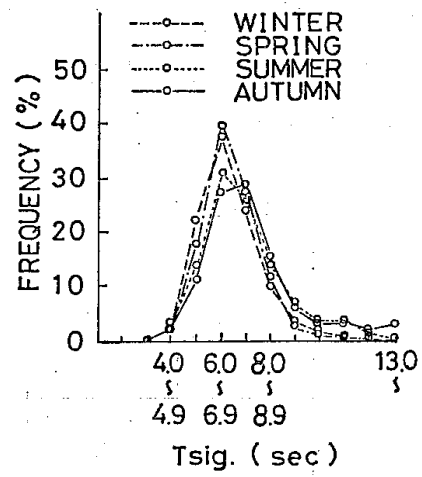

図-5 $1 / 3$ 有義波の周期 頻度分布 $^{16>}$

\section{4. 解析結果}

基盤に至るたい積深さが顕著に異なる三サイトで同時 に得た同時三成分観測記録はディジダル化し，MTに収 録して数值処理をした点浪報と同榜である。なお，解 析対象記録長さは 102.4 秒間である。

以下，項目ごとに結果を述心゙,三サイトのたい積深さ， 気象状態との関連で比較・考察する事にする。

4-1 スペクトルと台風
て打り，その後，日本に上陸し濃尾平野から $1500 \mathrm{~km}$ 離れた北海道知床岬沖で温带性低気压となり消滅した。 さて，長周期微動の発生メカニズムを箨者らは確認して いないが，波浪が陸地のどこかでぶつかり，そこが定常

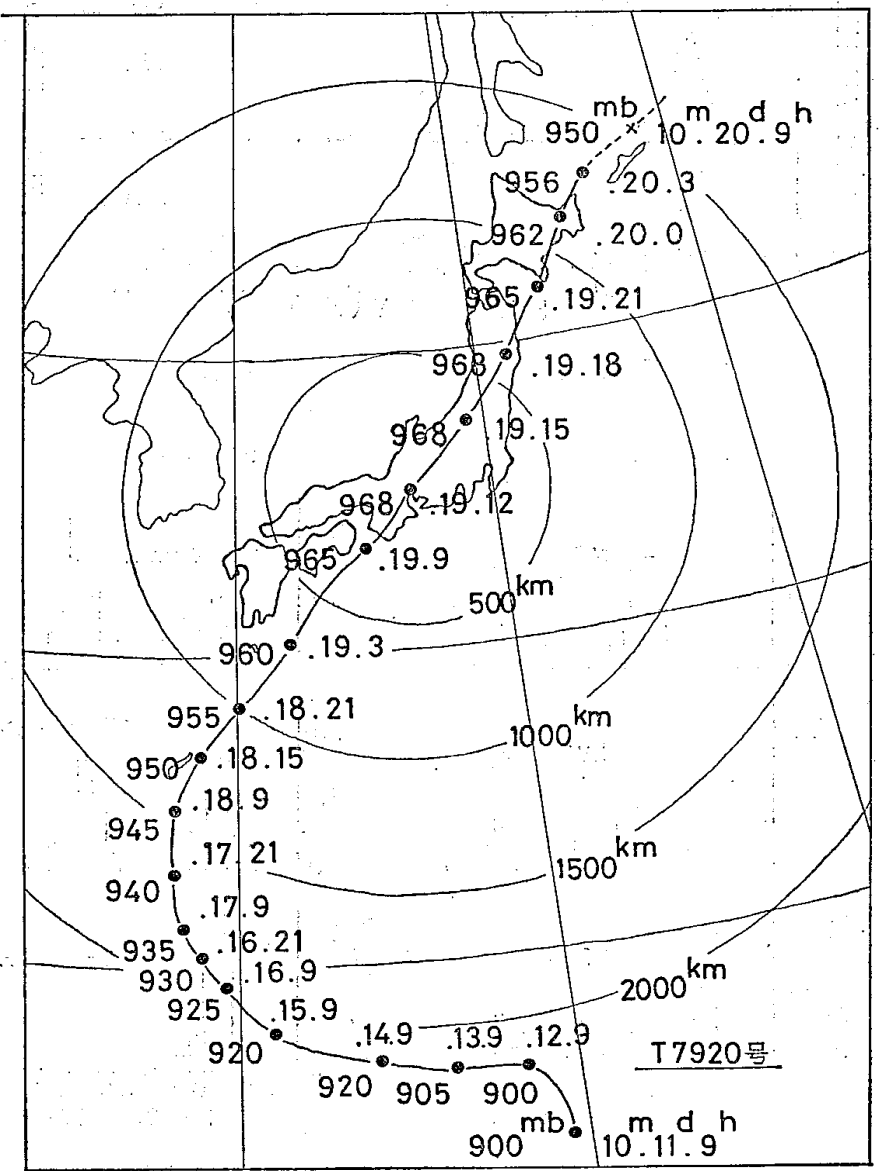

図一6 台風 7920 号の経路 
振動源となっていると言われている ${ }^{10)}$ 。とすれば，波浪 にも多大な影響を与えるであろう台風の進行と長周期微 動のスペクトルとの関わりにも関心が持たれる。

そこでいま，それらの相関性を大局的に把握寸る目的 で，気象外乱源である台風の経路を図一6に，台風の中 心位置が濃尾平野から $500 \mathrm{~km}$ の倍数の所にある時刻近 傍の各サイトに和ける三成分のスペクトルを図一7 に示 す。台風は九州・四国の南方を北西に進み和歌山県に上 陸した。その時の中心気圧は $965 \mathrm{mb}$, 最大風速は 70 ノ

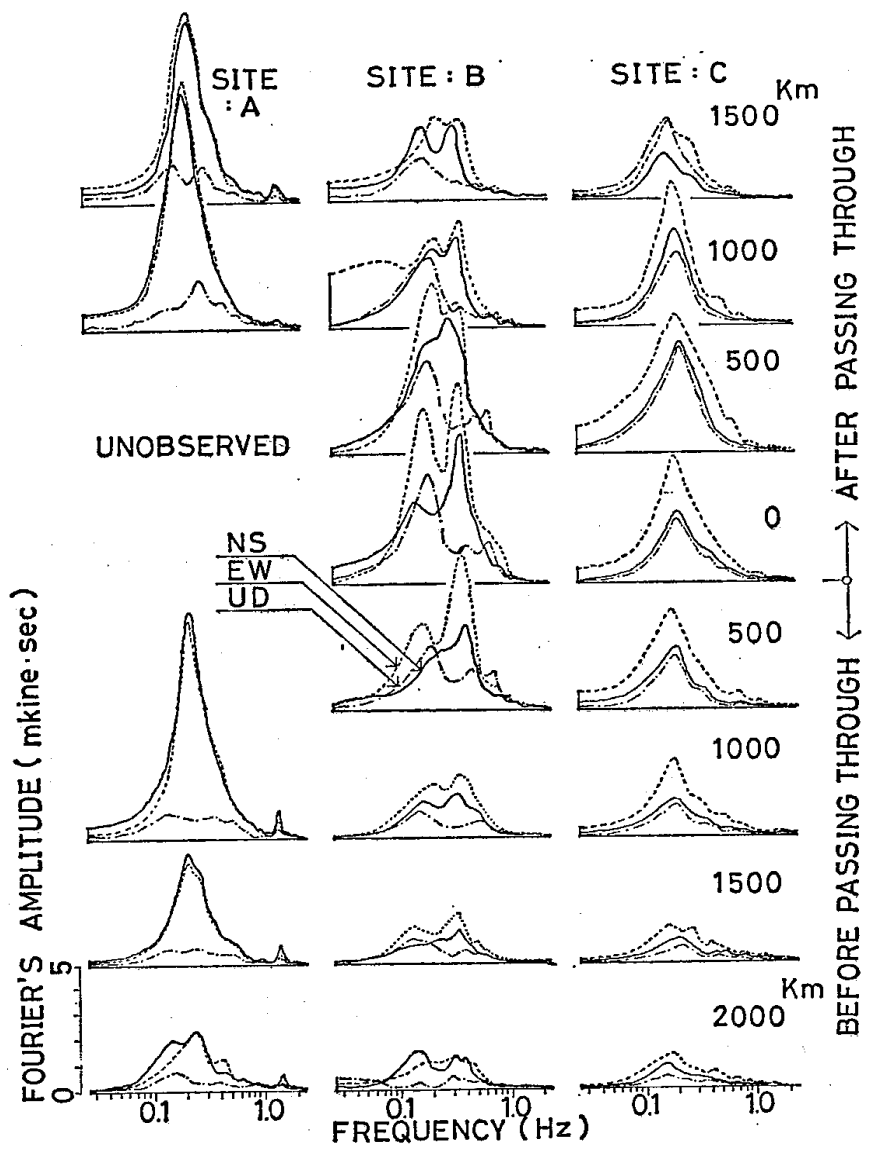

図一7 三サイトのスペクトル変化

SITE: A
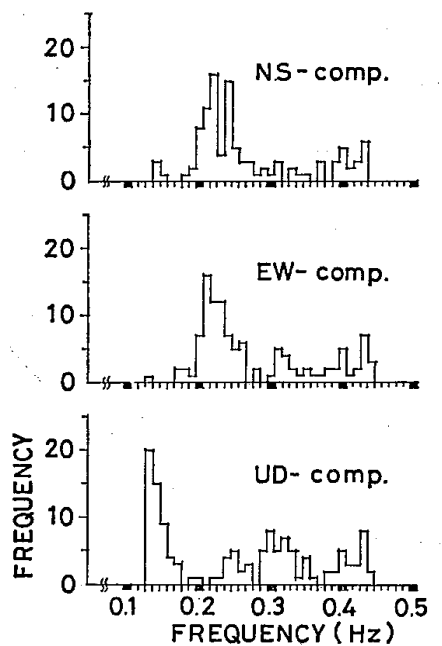

(a)
SITE : B
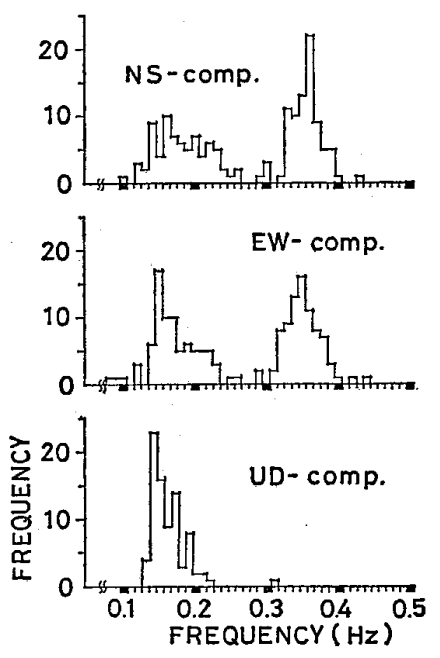

(b)
ット $(36 \mathrm{~m} / \mathrm{s})$ の大型台風で，その後はほぼ本州を縦断 する状態であった。なお，Aサイトでは屋外観測であり 台風が平野に近い時，すなわち図中で通過前後 $500 \mathrm{~km}$ の三ケースについては観測されていない。

フーリエ・スペクトルは，水平動 NS 成分を実線, $\mathrm{EW}$ 成分は破線，上下動成分は一点鎖線で表示してい る。スペクトル形状に関して概観すれば，フーリエ振幅 の大きさはAサイトが最大である。台風の位置が南方洋 上の $2000 \sim 1000 \mathrm{~km}$ の時，フーリ工振幅は，A サイト は B,Cサイトの 1.5 3 倍, 通過後 $1000 \sim 1500 \mathrm{~km}$ の場合には 2 倍程度となっている。これらは, 地盤剛性 の差違によるものの上に, 気象変化, 外乱源の特性など が影響しているものと言える。

また，A，Cサイトが単一のピークを有するのに対し，

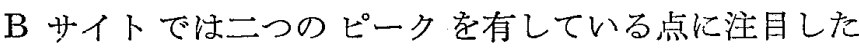
い。各サイトの各成分に共通して，南方洋上 $2000 \mathrm{~km}$ から平野に接近するに従って，各々のフーリエ振幅は大 きく変化している。そして, 通過後の振幅の方が通過前 のそれより大きく，この傾向は文献 17) での指摘と同様 である。

フーリエ・スペクトル自体に変化があるという事実は， 例えば，地盤の堆積深さとフーリエ振幅の対応関係を調 查する事它目的とするよ5な場合，静榣な気象状態のも とで観測する事が大切であるという事を示している。

また，卓越振動数の変化の様相について概観すれば， 各サイト各成分は台風位置に依存する事なく，大きく変 化していないかのごとく見受けられる。Bサイトのスペ クトルは双子山の形状を呈すが，その各々の卓越振動数 治台風といら異常気象状態下でもあまり変化していな い。以上から，本観測のごとき気圧配置，台風経路下で は卓越振動数はほとんど変化しないが，フーリエ振幅は 観測された各々の地盤のたい積層厚，剛性を反映しなが
SITE: C
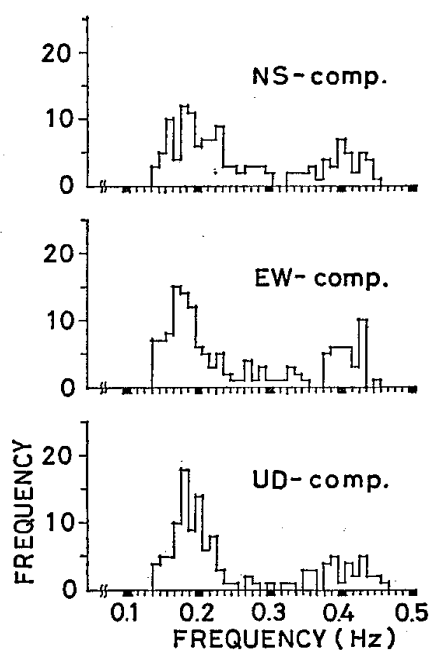

(c) ら台風の影響を示すと言 ら事加出来る。

4-2 三サイトの卓越 振動数の分布

前節で明らかとなった ように， $\mathrm{A} ， \mathrm{C}$ の二サイ トで注成分の卓越振動 数が単一のピークを示す のに対し，Bサイトでは 二つのピークを有してい る。図-7 は観測点のス ペクトルを台風の位置と の関係で眺めたものであ り，全観測データの卓越 振動数出現の状態がいか なるものかを把握するた

図一8 三サイトの卓越振動数頻度分布 
め，図一8 (a) (b) (c) に頻度分布を示す。同図は，第 一, 第二ピークの卓越振動数を共有の振動数軸で示して いる。Aサイトでは，水平動二成分が $0.20 \mathrm{~Hz}$ よりや 大きい值, 上下動成分は $0.13 \mathrm{~Hz}$ と $0.30 \mathrm{~Hz}$ の近傍に 分布している。Bサイトでは，水平動二成分が $0.35 \mathrm{~Hz}$ の近傍に，別に第二ピークとして三成分共に $0.15 \mathrm{~Hz}$ の 近くにも分布している。最後にCサイトでは， $0.17 \mathrm{~Hz}$
近傍で顕著なピークを与えている。

さて, 既報 ${ }^{1,2), 32}$ との関連で以上の分布について考察 すれば，A サイトの $0.20 \mathrm{~Hz} ， \mathrm{~B}$ サイトの $0.35 \mathrm{~Hz}$ に関 しては，岩盤に至る堆積深さが大きい事を反映して卓越 振動数が低いのであるとの説明が可能であるが，Bサイ トの第二ピーク，岩盤露頭に等しいCサイトの卓越振動 数が低い事に対する説明は，地盤そのものの特性として

(a)

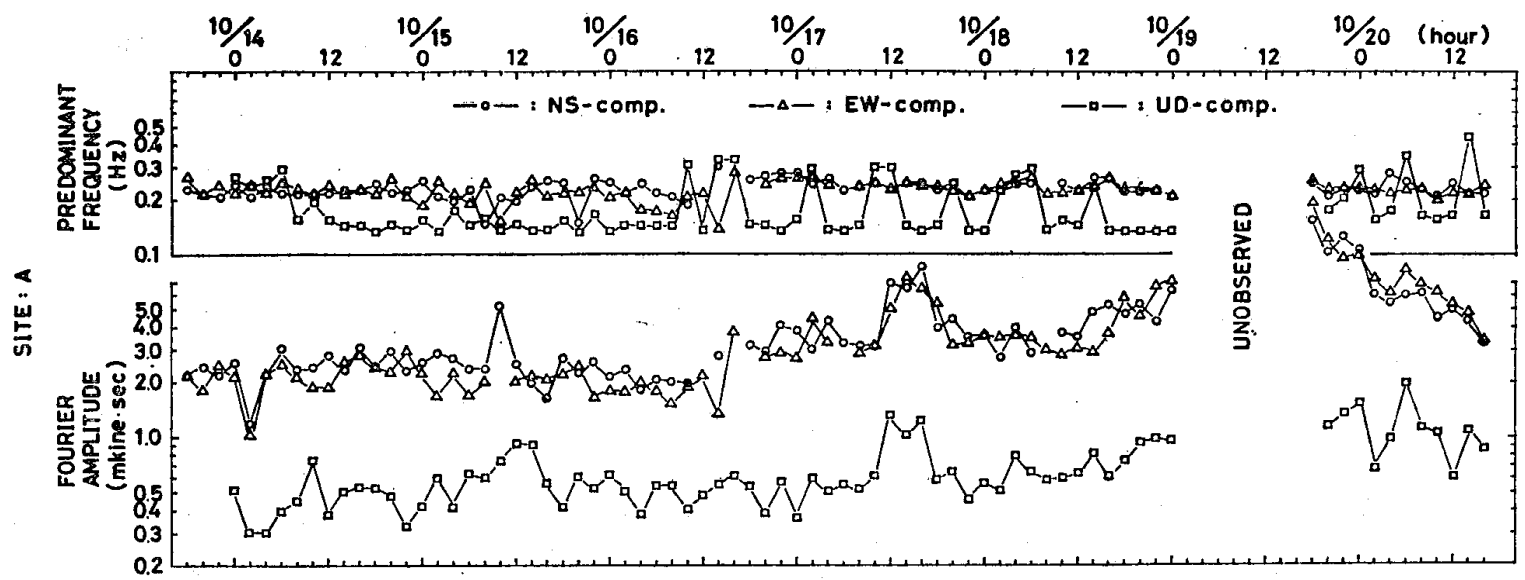

(b)

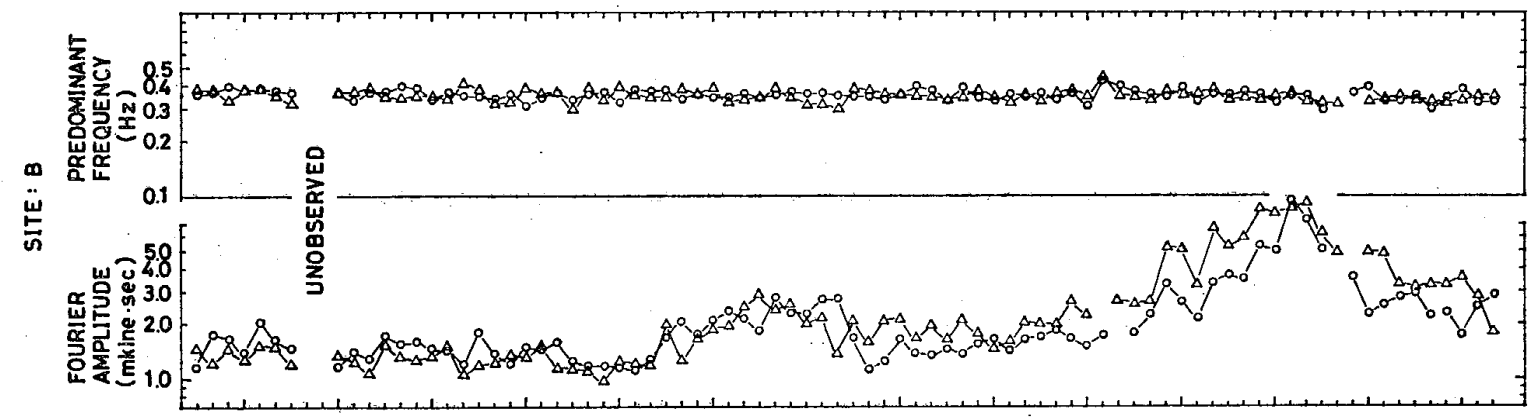

(c)

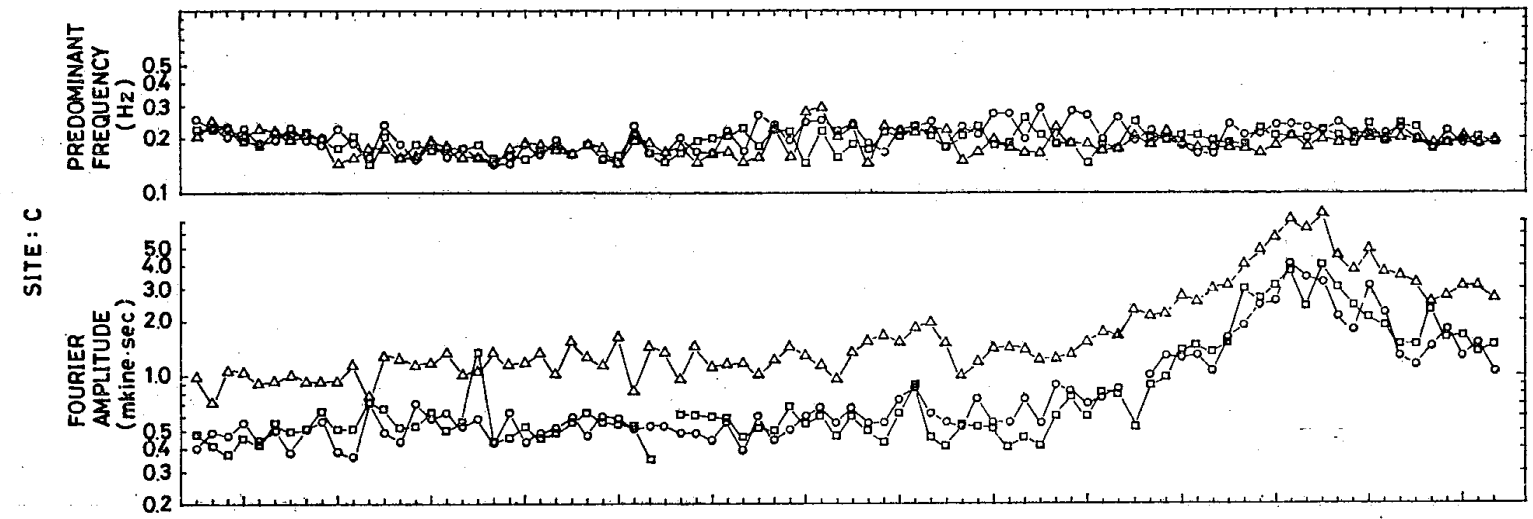

(d)

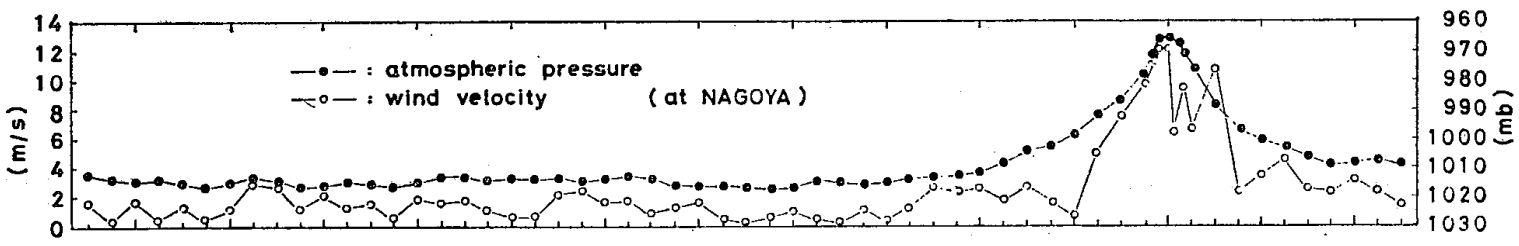

(e)

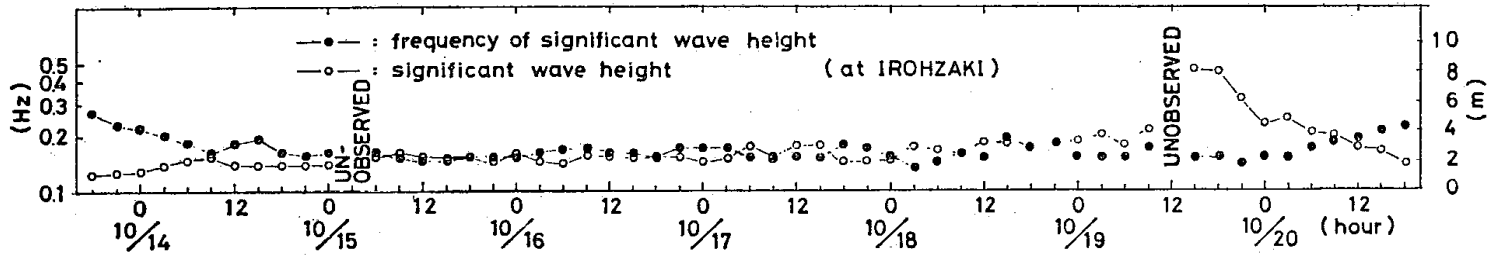

図一9 三サイトに㧍ける卓越振動数・フーリエ振愊と気象・波浪の関係 
説明する事は困難である。つまり，地盤振動特性そのも のではなく，外乱源の特性が出現しているものと推測さ れよ5。

4-3 卓越振動数・フーリエ振幅とたい積深さ，及び 気象・波浪との関係

各サイトでの三成分の卓越振動数・卓越フーリエ振幅 を，基盤に至るたい積深さ，そして名古屋地方気象台に 抢ける気象条件を示す現地気圧・風速との関連で考察す る。既報では波浪との関連性は，伊勢湾内の四日市港 沖，常滑沖 (図一1 参照) での記録を使用し，伊勢湾の 波浪の周期と濃尾平野内の地盤の長周期域での卓越周期 が 2 対 1 の関係にはない事を確認した。しかし，外洋波 浪周期との検討が必要で，本報では濃尾平野に近い波浪 観測場所である石廊崎（図一5 参照）での記録 ${ }^{16)}$ を参考 資料として検討する。

図一9 は各サイトでのすべての卓越振動数と卓越フー リエ振幅を, “(a)：A サイト,(b)：Bサイト,(c)：Cサ イトの順に記し，観測時の名古屋地方気象台での現地気 压を風速を（d），石廊崎でのゼロアップクロス法による $1 / 3$ 有義波の波高と振動数の 2 倍（1/2 周期）を（e）に 示している。

まず，(a)のAサイトは，図-1，図-2 から明らか なよらに岩盤に至るたい積層の深さは, $1000 \mathrm{~m}$ をはる が越えると推定される平野のかなり酉部に位置してい る。地盤固有の振動特性としてかなり長い周期が予想さ れよう。本サイトでの卓越振動数は, 水平動成分に関し ては $0.20 \sim 0.24 \mathrm{~Hz}$ に多くが分布しており，全観測デー タに括ける最高頻度の卓越は $0.22 \mathrm{~Hz}$ であるが,この值 は過去に単一回数で観測した本少イト近傍での卓越值と ほぼ同じ值である。これは平野西部で定常的に得られる 地盤固有の振動特性と考㝋られる。上下動成分怯，0.15 $\mathrm{Hz}, 0.30 \mathrm{~Hz}$ の二つの振動数の近傍域で卓越する場合が 多い。スペクトル中のピークの出現の㴍相は， $0.15 \mathrm{~Hz}$ を与光場合の形状はなだらかなものである。フーリエ 振幅は，水平動二成分は互に似た大きさを示し，上下動 成分は水平動成分の約 1/10 のオーダーである (102.4 秒 の解析記録長さを前提としている)。

一方，(b) に示されているB+イトにういて眺める。 本サイトの卓越振動数は，図一7, 図一8 (b) で明らかな ごとく二つのゾーンに見られる。前報引における本サイ トでの 1 年閒にわたる観測では，水平動成分の卓越振動 数は, $0.30 \sim 0.35 \mathrm{~Hz}$ の近傍が最高頻度で, 本報での第 一ピークに一致する。上下動成分については，これらの 振動数の近傍で明確なピークを示す状態になく，図中に 上下動成分を記入乙ていない。な扬，Aサイト，Bサイ トとも台風の接近に伴ってこれらの卓越振動数が大きく 変化している状態には無い。一方, さらに低振動数域で 第二ピークを示す点に注目する（図中にはプロットされ
ていない)。三成分共通して $0.15 \mathrm{~Hz}$ あたりが最高頻度 を示しており，この值はたい積層厚や過去の観測データ などから，地盤固有の振動特性とは異質のものと考えら れる。上記の傾向は，文献 13），での指摘に一致してい る。飯田・太田 ${ }^{13}$ の観測した台風の進路を破線で, 本研 究での台風進路は太実線で図一4に示している。

以上の Bサイト，Aサイトに打ける水平動成分の卓越 振動数が, 平野東部で $0.35 \mathrm{~Hz}$, 西部で $0.20 \mathrm{~Hz}$ 程度 である事は，定量的にも，東から西へ低く変化するとの 過去の静穏な気象状態のもとでの観測結果に一致する。 この事実は, 濃尾平野固有の振動特性を示している事を 裏付けるデータとなろう。

さて，たい積深さがほぼ皆無と考えて良いCサイトで は，(c) からわかるよらに三成分がほぼ $0.18 \mathrm{~Hz}$ 近傍に 分布して扔り， A， B 二サイトトと同様にたい積深さとの 関連で考える限り説明する事は困難である。明確な断言 はむつかしいが，A，B サイトと違ってフィルター作用 を果すたい積層が無い岩盤上に位置しており，長周期微 動の振動源とされている波浪による定常波の特性が淔接

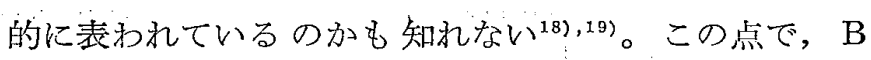
サイトの第二ピークの卓越振動数の $0.15 \mathrm{~Hz}$ と C サイ トの $0.18 \mathrm{~Hz}$ がかなり類似しているの璵味媣く, 明 確にするには伝播性の検討のための別途観測を実施する か, たい積深さの異なるサイトでの地震動と微動との対 応性の検討が必要となろら。

次に，(d)に示した 3 時閒ごとの風速・気压といら各 気像因子との関連で, 各サイトの卓越振動数と卓越フー リエ振幅の推移を眺めると, 卓越振動数がこれらの因子 の変化に対応して変化していると断定しにくいのに対 し，フーリエ振幅は極めて相関性が良いと言える。即 ち, 水平動成分の場合, 風速とフーリエ振幅の間の相関 係数は $0.70 \sim 0.76$, 気圧とフーリェ振幅の間のそれは 0.78 0.81 の間に分布している。また, 各サイトでフ ーリエ振幅の変化は 10 倍内外である。

な㧍，東京に扔ける小林・小林の報告 ${ }^{200}$ によれば，気 象条件によって振幅レベルのみならず, 卓越周期の相違 が観測されたとあるが，この傾向は，本観測でのBサイ トの一次の卓越振動数およびCサイトの卓越振動数の变 化の傾向と一致している。しかし，Aサイトでの卓越振 動数とBサイトでの二次の卓越振動数は台風によって変 化していない事から，これらの卓越振動数は地下構造の 特性を強く反映しているものと考えられる。

（e）は，石嫏崎での 3 時間ごとの波浪記録の $1 / 3$ 有義 波の 2 倍の振動数 (周期の $1 / 2$ ) と波高の変化を示して いる。2 倍の振動数の多くは, $0.15 \sim 0.18 \mathrm{~Hz}$ に分布し ている。ただし, 観測の初めと終りは, やや高い振動数 となって括り, 図-5に示した通常の波浪の周期に比 べ，2．倍近くに大きくなっている事がわかる。波浪の 2 
倍の振動数の值と変化の様相は, 岩盤上に位置するCサ イトの卓越振動数の值と変化のそれとかなり似ている。 これは，Bサイトでの第二ピークを与える振動数が同様 の傾向である事とも共通し, 地盤の振動特性の評価に当 り注意が必要となろう。つまり, 岩盤上では外乱源の特 性が，また，たい積層厚があまり大きくない場所では外 乱源とたい䡠層の両方の特性が現われやすいのではない かと考光られる。

卓越振動数が各少イトごとに少しずつ摇らいでいるの は，外乱源のスペクトル特性の変化に依存するものと考 えられる。また, 波高の変化の椂相と, フーリエ振幅・ 気压・風速の変化のそれとは似ている。

\section{4-4 統計学的に眺めた卓越振動数}

本節では，得られた卓越振動数を統計学的な観点から
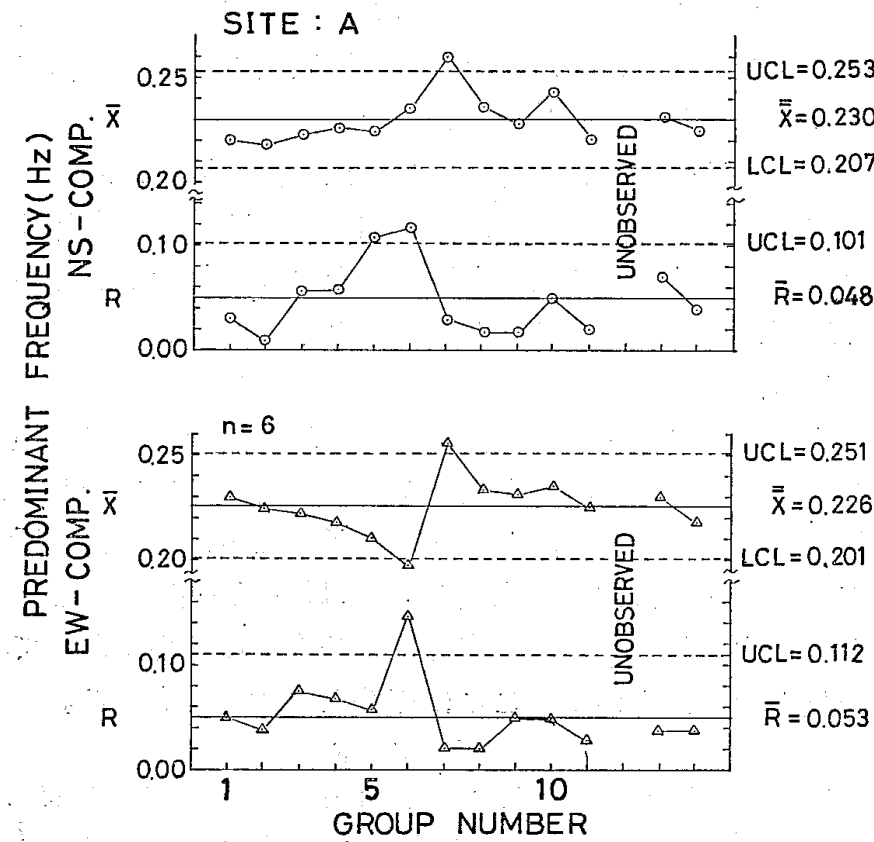

(a)

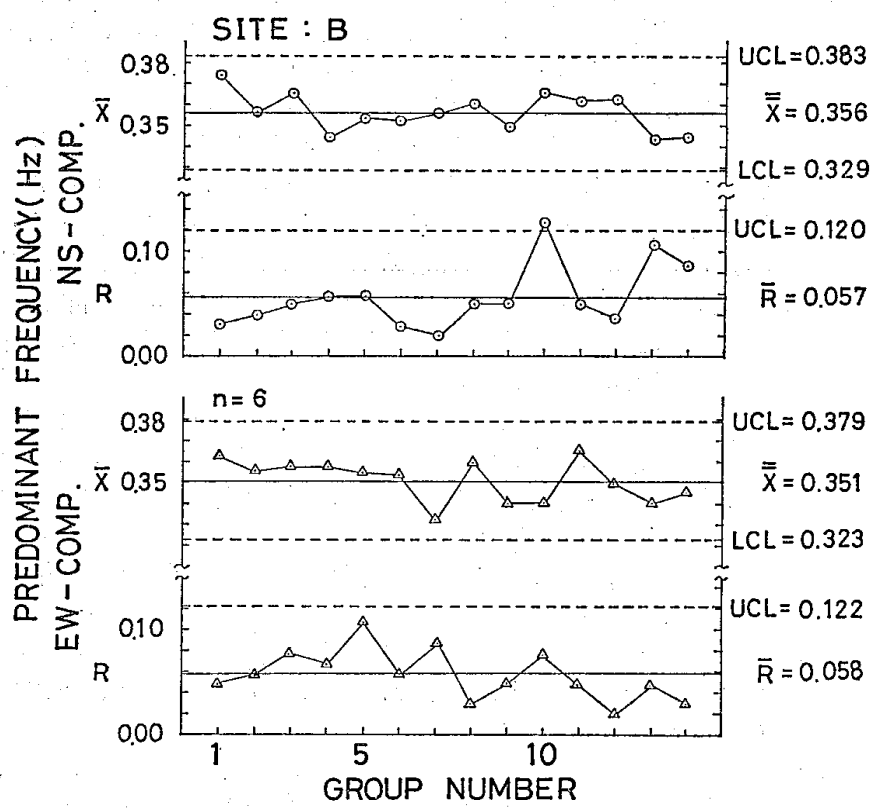

(b)
検討してみる。つまり，工程管理に利用される管理図， ここでは母集団とデータとが連続分布を通じて関係づけ ら机る計量值用管理図 $(\bar{x}-R \text { 管理図 })^{21}$ を使用して，各 サイトの卓越振動数の变化の特徵を考察する。

各サイトの卓越振動数（ 1 週間, 84 回分のデータ)を 半日ごと 6 回分（大きさ $n=6)$ のサンプル $(k=14$ 個）
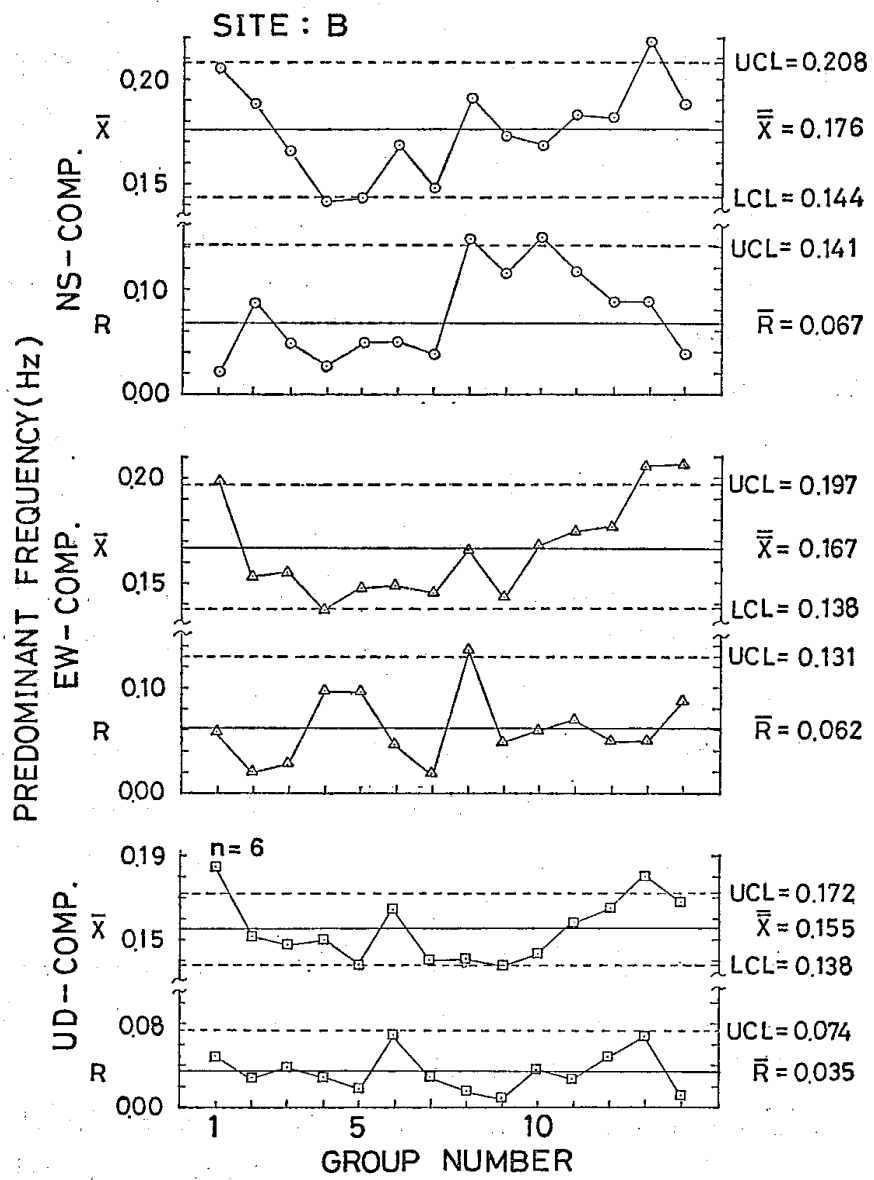

(c)

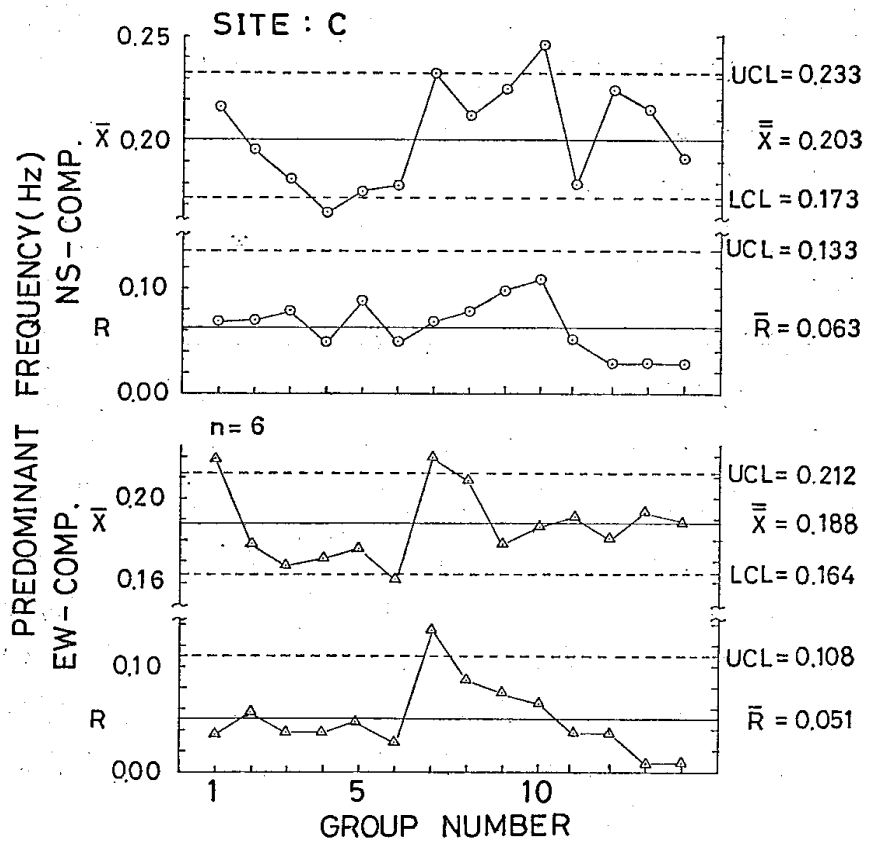

(d)

图-10 三サイトの卓越振動数に関する $\bar{x}-R$ 管理図 
について, 各々の節囲 $R_{i}(i=1 \sim 6), \bar{R}=\sum R_{i} / k$ 抢よ び上部管理限界線 UCL を求め $R$ 管理図とする。

次に，大きさ 6 のグループごとの平均值 $\bar{x}_{i}(i=1 \sim k)$ を求め,さらに $\overline{\bar{x}}=\sum \bar{x}_{i} / k$ を求める。また，上部管理 限界線，下部管理限界線（LCL）を算出し， $\bar{x}$ 管理図を 作成する。したがって， $R$ 管理図は母分散に関しての， また $\bar{x}$ 管理図は母平均に関する情報を示す事が分る。

図一10 は，各サイトの $\bar{x}-R$ 管理図を，(a)：A 少イ 卜，(b)：B サイト(第一ピーク)，(c)：B サイト（第 二ピーク)，(d)：Cサイトの順に記している。これら四 つの $\bar{R}$ 管理図に共通するのは, 限界線の上にとび出し た管理はずれが若干見られる。これは，むとの母集団に おける母分散が一様でない事を示している。全般的には 管理状態に近い。 $\bar{x}$ 管理図を眺めると，特徽は二つに大 別される。すな⿰ち，(a) と（b)，(c) と（d）の二組で ある。(c) 図では横軸に記した第 2 グループから第 10 グループまでは三成分が $\bar{x}$ を下まわる状態にあり，第 11 グループから $\overline{\bar{x}}$ を上わる傾向にある。濃尾平野か らの台風中心位置までの距離が, $-2000 \mathrm{~km} \rightarrow-1500$ $\mathrm{km} \rightarrow+1500 \mathrm{~km}$ と変化するのに伴い, 三成分のグル 一プの卓越振動数の平均值がおよそ $0.20 \mathrm{~Hz} \rightarrow 0.14 \mathrm{~Hz}$ $\rightarrow 0.20 \mathrm{~Hz}$ と, 減少 $\rightarrow$ 横ばい $\rightarrow$ 増大と変化している。 これは，気象因子・波浪など外乱の影響下にある事を如 実に示していると言えよう。

（d）図も一部の管理はずれのグループを除外すれば， （b）と同様の傾向がうかがわれる。また，(c) と（d）の $\overline{\bar{x}}$ は比較的近い值を示している。

以上の事は，前節で指摘した岩盤に至る深さが中程度 の地盤の第 2 ピークと岩盤に至る深さがほぼゼロに等し いサイトでの卓越は類似した要因が関係しているとの支 援材料になろう。一方，(a) と（b）は，地盤固有の振動 特性を示しているといら前節での見解を支持し得るデー タとなろう。

\section{5. ま と め}

濃尾平野における面的店がりを考慮した地盤動特性を 検討し，工学的利用を図る事を目的に微動観測を段階的

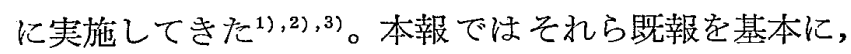
岩盤に至る堆積深さが $1000 \mathrm{~m}$ をはるかに越える地点, 数百 $\mathrm{m}$ の地点そしてほぼ $0 \mathrm{~m}$ の地点といった顕著に異 なる三サイトで同時に，一週間にわたり長周期微動の同 時三成分観測を実施した。同一気象状態のもとで, 異な る地下構造状態の三サイトで得られた長周期微動特性 を,たい積深さ・台風通過に伴う気象（風速，気圧）の 変化・外洋波浪特性そして卓越振動数に関して統計学的 観点から $\bar{x}-R$ 管理図を用いて比較・検討を実施した。 得られた結果を以下に要約する。

1）水平動成分の卓越振動数は，堆積深さが数百 $\mathrm{m} の$ サイトで約 $0.30 \mathrm{~Hz} ， 1000 \mathrm{~m}$ をはるかに越えるサイト
で約 $0.20 \mathrm{~Hz}$ を示し, 基盤に至るたい積深さに対応して いる。また, その值は天候が静箢な時と台風時とで大き く変化しない。

2）台風通過に伴ら気圧・風速の急変下で，あるいは 波浪の影響下で，たい積深さがほぼ $0 \mathrm{~m}$ に等しいサイ 卜と数百 $\mathrm{m}$ のサイトの第二ピークの卓越周期は, 外洋 波浪の $1 / 3$ 有義波の周期の $1 / 2$ に近く，定常波説との 関連性を暗示している。

3）フーリエ振幅は, 観測サイトの地下構造に関倸せ ずに，気圧の低下や風速の増大に伴って変化を示す。

4）堆積層が存在するサイトでは, 堆積層が一種のフ イルター作用を果した結果がスペクトル特性に表かれて いるものと考えられる。

5）たい積層が存在するサイトの卓越振動数は, 若干 の変動があるものの, 台風そのものの影響は小さく, 比 較的安定である。この事は, 長周期微動を工学的に利用 する際の有利な資料と考えられる。

な拉，長周期微動を対象とした伝播性の検討，或は， 平野周縁部を対象として, 長周期微動・地盤そして外乱 の関係を明確にするため卓越周期をどら評価するかとい う検討については，各々別報を予定している。

\section{謝 辞}

本観測は名大・多賀研, 愛工大・飯田研の合同で害施 したものである。特に名大助手・富㭴 豊氏には観測・ 解析そして日常の討論と大層叔世話になった。また，愛 工大助手・谷口仁士, 佐藤工業 $\mathrm{KK}$ (元 - 名大学生) 角谷豊史の諸氏, 各研究室各位の絶大なる協力があって 可能となったもので，ここに深甚なる謝意を表する。

\section{参考文 献}

1）多賀直恒 - 宮崎 正：“濃尾平野の長・短周期微動特性 (1)”, 日本建築学会論文報告集, 第 269 号, 昭和 53 年 7 月, pp. 103 114

2) 多賀直恒・宮崎 正 : “浱尾平野の長・短周期微動特性 (2) 一直交二測線の同時三成分計测一”，日本建築学会論 文報告集，第 273 号，昭和 53 年 11 月, pp. 33 42

3）多賀直恒・营崎 正：“浱尾平野の長・短周期微動特性 （3）一洪積台地上に拝ける定点長期計測一”, 日本建築学 会論文報告集，第 292 号，昭和 55 年 6 月, pp. 41 48

4）鏡味洋史・太田 裕・後藤典俊・塩野計司・工藤一嘉・ 坂宄直已・成瀬聖意・出原孝示・竹内文朗：“やや長周期 の微動観測已地震工学への適用 (3) -1968 年十勝沖地震 の SMAC 型强震計記録との比較一”, 地震第 2 輯, 第 29 号 (1976), pp. 147 158

5）多賀直恒・浅野利三郎・小島時和：“地中・地表の地震動 観測及び常時微動計測による地盤振動性状（その 1), (そ の 2 )", 建筑大会梗概集, 昭和 54 年 9 月, pp. 509 512

6）多賀直恒・富樫 䟧: “トリパータイト観測に上る平野の 微動の伝播性について”, 建築大会梗概集, 昭和 55 年 9 月, pp. $455 \sim 456$

7) M.S. Longuet-Higgins : "A Theory of the Origin of Microseisms", Phil. Trans. Roy. Soc. London, A.243 (1950), 1, pp. 1 35

8) Fuyuhiko Kishinouye : "Microseisms and Sea Waves", Bull. Earthq. Res. Inst. Vol. 29 (1951), pp. 577 582 
9) Fuyuhiko Kishinouye and Mieko Kotaka: "Microsesims and Typhoons", Bull. Earthq. Res. Inst., Vol. 37 (1959), pp. 171 176

10）三東哲夫：“波浪はどこで脈動に変わるか？”地震，第 2 咕, 第 13 巻, 第 3 号, 昭和 35 年, pp. 150 162

11）三東哲夫：“波浪㤝どこで脈動に変わるか？(続) - scandinavia の脈動—”, 地震, 第 2 輯, 第 16 巻, 1963, pp. 165 180

12) Ryohei Ikegami and Fuyuhiko Kishinouye : "A Study on the Propagation of Microseismic Waves. Part II", Bull. Earthq. Res. Inst., Vol. 28, 1950, pp. 115 119

13) Kumizi Iida and Yutaka Ohta : A Study of Microseisms Observed in Nagoya and Iits Vicinity", Journal of Earth Sciences, Nagoya University, Vol. 12, 1964, pp. 192 221

14）松沢 勲・桑原 徹：“濃尾平野の地下構造とその構成”, 伊勢湾台卮災害の調查研究報告，1664, pp. 14 39

15）中部圈基盤構造研究 グループ：“名古屋地域の基盤構造
(その 1 )”，地震学会講演子稿集，1980，No. 2, p. 211

16）気象庁：“気象庁波浪観測資料”第 3 号，昭和 55 年 3 月

17）和達清夫・井上宇扸・広野卓蔵：“台風と脈動との関係に ついて” 験震時報, 第 21 巻別冊, 1956, pp. 3 10

18）：成瀬聖慈・出原孝示 - 竹内文朗 - 太因 裕 - 鏡味洋史 後藤典俊・塩野計司・工藤一嘉・坂尻直己：“やや長周期 の微動観測と地震工学への適用 (2) 一微動の卓越周期と 地下構造の関係一”地震，第 2 輯，第 29 巻， 1976，pp. $25 \sim 32$

19）神山 真・松川忠司：“地盤の強震時と微小振動時におけ る振動特性の関係について”，第 15 回土質工学研究発表 会, 1980 , pp. 1213 1216

20）小林啓美・小林喜久二：“地盤のやや長周期微動にみられ る地盤特性”，建築大会梗概集，昭和 52 年 10 月, pp. 509 $\sim 510$

21）近藤良夫・般阪 渡：“技術者のための統計的方法”共立 出版, 昭和 52 年

\section{S Y N OPSIS}

UDC: $: 624.131 .55: 624.042 .7: 550.34$

\section{MICROSEISIMS IN THE NOHBI PLAIN (PART 4)}

One week observation on three different soil deposits -

by Dr. NAÓTSUNE TAGA Nagoya Univ. and TADASHI MIYAZAKI, Members of A.I.J.

Continued to the previous papers, microseismic observations were carried out by use of the seismometers with period of 10 seconds and 5 seconds. According to the geological survey, the observed sites are classified into three different layer thickness of soil deposits on the bed rock. Namely, their bed rocks locate zero, moderate and very deep in depths. The observation was carried out every two hours for one week since October 13 in 1979.

The purpose of this paper is to discuss the characteristics of ground vibration dedending on the different layer thickness of soil deposits on the bed rock under the simultaneous observation, i.e. under the same weather condition. Observed results are not only investigated in low frequency properties as to the thickness of soil deposits but also studied in view of wind velocity, atmospheric pressure and frequency of significant wave height which was induced by typhoon T 7920.

The main results are as follows.

(1) Predominant frequency of horizontal components on moderate and very thick soil deposits corresporids to the layer thickness of soil deposits on the bed rock.

(2) Predominant frequency on the outcrop of the bed rock may be able to be explained by the theory of "stationary waves" due to sea waves.

(3) Fourier's amplitude is closely related to the level of wind velocity and atmospheric pressure.

(4) It is assumed that spectral characteristics has the results of a kind of filtering effect due to soil deposits except for the microseismic observation on the outcrop of the bed rock.

(5) Microseismic observation on the soil deposits will be useful for the purpose of engineering use. 